\title{
Marginal and Internal Adaptation of Zirconia Endocrowns - A Literature Review
}

\author{
Mehrnaz Karimi Afshar ${ }^{1}$, Hosseinali Mahgoli², Saied Nokar ${ }^{3}$, Mehran Bahrami $^{4}$ \\ 1Department of Prosthodontics, School of Dentistry, Tehran University of Medical Sciences, Tehran, Iran. ${ }^{2}$ Department \\ of Prosthodontics, School of Dentistry, Tehran University of Medical Sciences, Tehran, Iran. ${ }^{3}$ Department of \\ Prosthodontics, School of Dentistry, Tehran University of Medical Sciences, Tehran, Iran. ${ }^{4}$ Department of \\ Prosthodontics, School of Dentistry, Tehran University of Medical Sciences, Tehran, Iran.
}

\section{ABSTRACT}

\section{BACKGROUND}

One of the important factors in the success of teeth with endocrown restorations is to achieve minimum values of internal and marginal gap. The purpose of this review article is to explore the information published in the marginal and internal adaptations of zirconia endocrowns.

\section{METHODS}

This review article was conducted using keywords of CAD/CAM, Endocrown and Marginal and internal adaptation in the Medline database. The search range included all relevant articles by the end of 2018.

\section{RESULTS}

The results of this study showed that 12 studies by the end of 2018 examined marginal and internal adaptation of endocrowns. Most studies were conducted in laboratory conditions. A majority of studies, which compared CAD/CAM systems, showed that the compared groups in terms of marginal and internal adaptation of endocrowns were in the clinically acceptable range in most cases.

\section{CONCLUSIONS}

A review of included studies showed that the endocrowns have the same or better marginal and internal adaptation compared to conventional crowns. However, there is a need for further studies with larger sample size and clinical trials in this area.

\section{KEY WORDS}

Endocrown, Marginal Adaptation, Internal Adaptation, CAD/CAM
Corresponding Author: Mehran Bahrami, Department of Prosthodontics, School of Dentistry, Tehran University of Medical Sciences, North Karegar Street, Tehran, Iran. E-mail: m.bahrami.sina@gmail.com

DOI: $10.14260 /$ jemds/2019/755

Financial or Other Competing Interests: None.

How to Cite This Article:

Afshar MK, Mahgoli H, Nokar S, et al. Marginal and internal adaptation of zirconia endocrowns- a literature review. J. Evolution Med. Dent. Sci. 2019;8(46): 3488-3491, DOI: 10.14260/jemds/2019/755

Submission 27-08-2019, Peer Review 31-10-2019, Acceptance 06-11-2019, Published 18-11-2019. 


\section{BACKGROUND}

Endocrown is an integrated restoration that is made due to advances in adhesion techniques for teeth with history of endodontic treatment.(1) This restoration consists of a crown portion and a cavity portion inside the pulp chamber, where the surface of the pulp chamber is used to stabilize and fix the restoration through a cement adhesive instead of the postcore system. The manufacture of endocrowns has been facilitated in recent years due to advances in CAD/CAM (computer-aided design and computer-aided manufacturing) technology. Endocrowns, as a suitable substitute for the crown, are useful when reconstructing posterior endodontic teeth, especially in teeth with a minimum crown height that has sufficient tissue for stable cement.(2)

The benefits of endocrowns include no need to increase crown length, no need for technical steps such as post cement construction and no need for core construction and temporary restoration.(3) The clinical success rate of these treatments has also been reported to be in the range of $94 \%$ $100 \%$, which is high statics. $(4)$

Achieving minimum values of internal and marginal discrepancy is one of the basic parameters in dental restoration.(5) Marginal gap causes dental plaque accumulation,(6) cement dissolution, periodontitis(7) or decay, ${ }^{(8)}$ and ultimately fracture of restoration. The acceptable clinical limit is $120 \mu \mathrm{m}$ for the marginal gap in the restorations. (9) Primary CAD/CAM restoration had a poor adaptation with a gap of more than $270 \mu \mathrm{m}$.(10) The range of marginal gap values for CAD/CAM restoration has been reported differently before the cementation, ranging from 85 to $247 \mu \mathrm{m}$.(11) In this regard, and with the advancement of technology, CAD/CAM has improved the amount of marginal adaptation of restoration significantly.(12)

During the process of making restoration with CAD/CAM, manufacturing accuracy is affected by various factors, such as scanning, geometric data processing, calculating milling parameters, actual milling process, and ceramic shrinkage during the sintering process.(13) Due to the variability of these parameters in various CAD/CAM systems, the role of the system must be considered about the dimensional changes and the accuracy of marginal restoration.(12)

Regarding the internal and marginal gap of endocrowns, one of the important factors in the failure of treatment, this study examined the information published on marginal and internal adaptation of zirconia endocrowns.

\section{METHODS}

This review article was conducted using keywords of CAD/CAM, Endocrown and Marginal and internal adaptation in the Medline database. The search range included all relevant articles by the end of 2018. Totally, 66 articles were found in this field. Only clinical and laboratory trials on endocrowns were enrolled in analysis; case reports, case series, pilot studies, review articles, and laboratory studies aimed at evaluating the characteristics of endocrowns, excluding marginal and internal adaptation, were excluded from the study. Finally, 12 articles on marginal and internal adaptation of endocrowns were investigated.

\section{RESULTS}

Of the articles reviewed, 12 articles related to marginal and internal adaptation of zirconia endocrowns were reviewed. The demographic characteristics of the articles studied are presented in Table 1. These articles compared CAD/CAM systems or different depths of milling cavity and its effect on marginal and internal adaptation of endocrowns. Table 2 shows the compared groups and the corresponding outcomes.

\begin{tabular}{|c|c|c|c|}
\hline Country & Type of Study & Year & Author \\
\hline Swiss & Retrospective Clinical trial & 1999 & Bindl \\
\hline Spain & In vitro & 2013 & Ramirez-Sebastia \\
\hline Egypt & In vitro & 2015 & Abo Elmagd \\
\hline India & In vitro & 2015 & Rajan \\
\hline Swiss & In vitro & 2016 & Rocca \\
\hline United Arab Emirates & In vitro & 2016 & Gaintantzopolou \\
\hline Egypt & In vitro & 2016 & El Guindy \\
\hline Syria & In vitro & 2016 & Dallout \\
\hline Korea & In vitro & 2017 & Shin \\
\hline Egypt & In vitro & 2017 & Darwish Ahmed \\
\hline Germany & In vitro & 2018 & Taha \\
\hline Swiss & In vitro & 2018 & Rucca \\
\hline Table 1. Demographic Characteristics of Studies \\
\hline \multicolumn{4}{|l}{} \\
\hline
\end{tabular}

\begin{tabular}{|c|c|c|c|c|}
\hline$\underset{\mathscr{U}}{\stackrel{\mathscr{U}}{3}}$ & 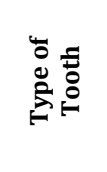 & 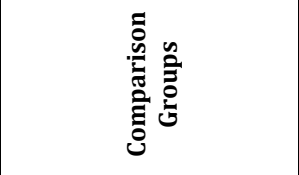 & 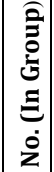 & $\sum_{\substack{0 \\
\vdots}}^{n}$ \\
\hline $\begin{array}{l}\text { After } 2 \text { years clinical quality } \\
\text { (adaptation) } \\
\text { CEREC endocrown were } \\
\text { very good } \\
\end{array}$ & $\begin{array}{l}\text { Molar and } \\
\text { premolar }\end{array}$ & CEREC & 19 & Bindl(1) \\
\hline $\begin{array}{c}\text { Endo cpr, Spcer, LPcpr } \\
\text { Showed the most marginal } \\
\text { integration. Effect of post } \\
\text { length on marginal } \\
\text { adaptation was not } \\
\text { significant. } \\
\end{array}$ & incisor & $\begin{array}{c}\text { 1-Lpcer Lp= long post, 2-Spcer } \\
\text { Sp= short post, 3-LPcpr cer= } \\
\text { ceramic CAD/CAM, 4-Spcpr } \\
\text { cpr= composite CAD/CAM, 5- } \\
\text { Endo cer Endo = endocrown, 6- } \\
\text { Endo cpr }\end{array}$ & $\begin{array}{l}48 \\
(8) \\
\end{array}$ & $\begin{array}{l}\text { Ramirez- } \\
\text { Sebastia }^{(14)}\end{array}$ \\
\hline $\begin{array}{c}\text { Marginal design had no } \\
\text { significant effect on vertical } \\
\text { marginal gap. endocrown } \\
\text { with butt margin showed } \\
\text { lesser micro leakage than } \\
\text { shoulder margin. } \\
\end{array}$ & premolar & $\begin{array}{l}\text { 1- Fiber post conventional } \\
\text { crown, 2- Endocrown with } \\
\text { butt margin, 3- Endocrown } \\
\text { with shoulder finish line }\end{array}$ & $\begin{array}{l}15 \\
(5)\end{array}$ & $\begin{array}{c}\text { Abo } \\
\text { Elmagd(15) }\end{array}$ \\
\hline $\begin{array}{c}\text { Marginal adaptation in } \\
\text { CEREC-In Lab MC XL was } \\
\text { better than CERAMILL. both } \\
\text { system coping had acceptable } \\
\text { internal adaptation and } \\
\text { marginal adaptation } \\
\end{array}$ & molar & $\begin{array}{c}\text { 1- CERAMILL } \\
\text { 2-CEREC-In Lab MC XL }\end{array}$ & $\begin{array}{c}20 \\
(10)\end{array}$ & Rajan(16) \\
\hline \begin{tabular}{|c|} 
In all groups complete \\
marginal adaptation after \\
loading were significantly \\
lesser than before loading. \\
There were no significant \\
differences between marginal \\
adaptation before and after \\
loading in experimental \\
groups. \\
\end{tabular} & molar & $\begin{array}{l}\text { 1-Hybrid resin composite(GC), } \\
\text { 2- } 1 \text { covered by } 3 \text { Meshes of E } \\
\text { glass fibres, } 3 \text {-FRC resin, 4-3 } \\
\text { covered by } 3 \\
\text { Meshes of E glass } \\
\text { fibres }\end{array}$ & $\begin{array}{l}32 \\
(8)\end{array}$ & $\operatorname{Rocca}^{(3)}$ \\
\hline $\begin{array}{c}\text { Significant differences } \\
\text { between marginal and } \\
\text { internal marginal gap in } 3 \\
\text { groups were seen. No } \\
\text { expansion in root showed } \\
\text { lesser gap. }\end{array}$ & $\begin{array}{l}\text { resin } \\
\text { endodonti } \\
\text { c tooth } \\
\text { models }\end{array}$ & $\begin{array}{l}\text { 1-Endocrown with intracoronal } \\
\text { preparation depth of } 2 \mathrm{~mm}, 2 \text { - } \\
\text { Endocrown with extra } 1 \mathrm{~mm} \\
\text { extension in the root canal } \\
\text { intraradicular, } 3 \text { - Endocrown } \\
\text { with extra } 2 \mathrm{~mm} \text { extension in } \\
\text { the root canal intraradicular }\end{array}$ & & $\begin{array}{c}\text { Giant- } \\
\text { Antzopolou } \\
\text { (17) }\end{array}$ \\
\hline $\begin{array}{l}\text { Vertical marginal gap was } \\
\text { significantly more in E. Max } \\
\text { CAD. vertical marginal gap } \\
\text { in both groups were in } \\
\text { Clinical acceptable range. }\end{array}$ & molar & $\begin{array}{l}\text { 1- LAVA Ultimate } \\
\text { 2-E. Max CAD }\end{array}$ & $\begin{array}{c}8 \\
(4)\end{array}$ & $\begin{array}{c}\text { El } \\
\text { Guindy(18) }\end{array}$ \\
\hline $\begin{array}{c}\text { Results show endocrown had } \\
\text { better marginal adaptation } \\
\text { than conventional } \\
\text { crowns(47). } \\
\end{array}$ & molar & & $\begin{array}{c}20 \\
(16)\end{array}$ & Dallout ${ }^{(19)}$ \\
\hline $\begin{array}{c}\text { endocrown with a 4-mm } \\
\text { cavity showed a larger } \\
\text { marginal and internal volume } \\
\text { than one with a 2-mm cavity. } \\
\end{array}$ & molar & $\begin{array}{l}\text { 1-CEREC AC with } 2 \mathrm{~mm} \text { cavity } \\
\text { depth, 2-CEREC AC with } 4 \mathrm{~mm} \\
\text { cavity depth, 3-E4D with } 2 \mathrm{~mm} \\
\text { cavity depth, 4-E4D with } 4 \mathrm{~mm}\end{array}$ & $\begin{array}{c}48 \\
(12)\end{array}$ & $\operatorname{Shin}^{(20)}$ \\
\hline
\end{tabular}




\begin{tabular}{|c|c|c|c|c|}
\hline $\begin{array}{l}\text { Both CAD/CAM systems } \\
\text { similar discrepancy in the } \\
\text { endocrowns }\end{array}$ & & cavity depth & & \\
\hline $\begin{array}{c}\text { Resin nano ceramic } \\
\text { endocrown showed better } \\
\text { internal adaptation than } \\
\text { lithium disilicate }\end{array}$ & premolar & \begin{tabular}{|c|} 
1- LS10 L=Lava, 2-LS6b E=IPS e. \\
max, 3-LD10 S=shallow depth(3 \\
mm), 4-LD6 D=extended \\
depth(5 mm), 5-ES10 6, 10- \\
degree axial wall, 6-ES6 \\
divergence, 7-ED10, 8- ES6 \\
\end{tabular} & \begin{tabular}{|l|}
40 \\
$(5)$ \\
\end{tabular} & $\begin{array}{c}\text { Darwish } \\
\text { Ahmed(21) }\end{array}$ \\
\hline $\begin{array}{l}\text { All groups showed acceptable } \\
\text { range in marginal adaptation, } \\
\text { but significant differences } \\
\text { were seen in gap after } \\
\text { cementation and } \\
\text { thermomechanical aging } \\
\end{array}$ & molar & $\begin{array}{l}\text { 1-Lithium disilicate ceramics } \\
\text { (LSC), 2-Polymer infiltrated } \\
\text { ceramics, 3-Zirconia reinforced } \\
\text { LSC, 4- Resin nanoceramics }\end{array}$ & $\begin{array}{l}40 \\
(10)\end{array}$ & Taha ${ }^{(22)}$ \\
\hline $\begin{array}{c}\text { There were no significant } \\
\text { differences between group } 2 \\
\text { and } 3 \text { with classic crown, but } \\
\text { there were significant } \\
\text { differences between groups } \\
\text { before and after loading. }\end{array}$ & premolar & $\begin{array}{l}\text { 1- no endocore (negative } \\
\text { control), } 2 \text {-endocrown with } \\
\text { end- core of } 2 \mathrm{~mm} \\
\text { 3- endocrown with end- core of } \\
4 \mathrm{~mm}, 4 \text { - crowns with post and } \\
\text { core (positive control) }\end{array}$ & $\begin{array}{l}48 \\
(12)\end{array}$ & Rucca $^{(23)}$ \\
\hline \multicolumn{5}{|c|}{ Table 2. The Compared Groups and the Corresponding Main Outcomes } \\
\hline
\end{tabular}

\section{DISCUSSION}

Most of these studies have compared CAD/CAM systems or different milling depths. Only four studies have pointed to the comparison of conventional crown with endocrowns. Among these four studies, Daullet et al.(19) and Abo Elmgad et al.(15) reported that the endocrown had a better marginal adaptation than conventional crowns, while Rocca et al. found no significant difference in the margin integrity between endocrown and classic crown groups.(23) As well, Ramirez-Sebastia(14) showed that there is no difference between endocrowns and crowns in the marginal adaptation after loading.

Most studies were related to recent years (2013 onwards) and within vitro design. Only one study in 1999 was a clinical trial, which determined the survival rate and clinical quality of ECEC endocrowns after two years. According to the results, endocrown 19 function time was 14-35.5 months and the molar endocrown 1 was eliminated after 28 months due to decay recurrence. Overall, the clinical quality of CEREC endocrowns was very well reported, and this clinical approach also seemed to be applied.(1)

In most studies, the rate of marginal adaptation in all groups after loading was significantly lower than before. However, there was no significant difference after loading between the groups compared in some of these studies, including those by Taha and Rucca. (3,22, and 23) However, some studies indicate a significant difference between the groups. For example, Darwish Ahmad(21) found that resin nanoceramic endocrowns exhibited a better internal adaptation than lithium disilicate. EL Guindy suggested that the mean vertical marginal gap in the Emax CAD group was significantly higher than the LAVA Ultimate group.(18) Rajan(16) showed that the marginal adaptation of the CERECIn Lab MC XL system was greater than the CERAMILL system.

Among studies, Shin et al. reported the values of internal and marginal gap of endocrowns with different depth values through micro-CT tomography calculations. According to the results, endocrowns with 4-mm cavity showed larger internal and marginal discrepancies than endocrowns with 2-mm cavity. The cementation process did not produce significant differences in terms of total gap thickness. In addition, the gap values in the pulp chamber floor were estimated to be higher than other areas. Both CAD/CAM systems (CEREC AC and E4D) showed similar gap values in endocrowns. Therefore, the values of the internal and marginal gap in the endocrowns in terms of increasing the cavity depth and the cementation process had no effect on increasing the dimensions of the gap between the restoration and the cavity wall. On the other hand, the gap value in the pulp chamber floor appeared to have had an impact on these results.(20)

Gaintantzopolou et al. assessed the effect of preparation and intracanal dressing on the marginal and internal adaptation of CAD/CAM endocrowns. In this study, Vita Enamic endocrowns were evaluated in three groups, including 2-mm intracoronal milling depth without intracanal dressing, 1- and 2-mm intracanal dressings. The results showed that lack of intracanal dressing showed the least gap value.(17) Ahmed Darwish et al. also examined the internal adaptation of lithium disilicate and resin nanoceramic endocrowns with different preparation designs. This study evaluated the effect of axial wall convergence $\left(6\right.$ and $\left.10^{\circ}\right)$ and the prepared depth ( 3 and $5 \mathrm{~mm}$ ) of IPS Emax CAD and Lava Ultimate endocrowns. All restoration was made by CEREC CAD/CAM system. The results of this study showed that resin nanoceramic endocrowns regardless of milling design had a better internal adaptation compared to lithium disilicate endocrowns.(21) Abo Elmagd et al. (2015) investigated the effect of marginal milling design on the microleakage and the marginal gap of endocrowns cemented with resin cements. This study evaluated the vertical marginal gap and the microleakage of lithium disilicate endocrowns with butt margin and shoulder finish line with 1-mm width and 2-mm axial wall height. The results showed that the marginal milling design had no significant effect on the vertical marginal gap. The endocrowns with butt margin showed less microleakage than the shoulder margin.

A review of studies showed that only one study(14) used maxillary anterior teeth for comparison. In this study, Ramirez-Sebastia et al. measured the effect of post length on marginal adaptation. The results showed that the post length had no significant effect on marginal adaptation. However, the rest of the studies were done on the posterior teeth. Due to different forces on posterior and anterior teeth, there is a need for further studies on anterior teeth.

\section{CONCLUSIONS}

A review of included studies showed that the endocrowns have the same or better marginal and internal adaptation compared to conventional crowns. However, the results should be interpreted with caution due to the laboratory design of most studies and there is a need for further studies with larger sample size and clinical trials in this area.

\section{REFERENCES}

[1] Bindl A, Mörmann WH. Clinical evaluation of adhesively placed CEREC endocrowns after 2 years: a preliminary results. J Adhes Dent 1999;1(3):255-65.

[2] Lander E, Dietschi D. Endocrowns: a clinical report. Quint Int 2008;39(2):99-106. 
[3] Rocca GT, Saratti CM, Poncet A, et al. The influence of FRCs on marginal adaptation of CAD/CAM composite resin endocrowns after simulated fatigue loading. Odontology 2016;104(2):220-32.

[4] Sedrez-Porto JA, da Rosa WL, da Silva AF, et al. Endocrown restorations: a systematic review and metaanalysis. J Dent 2016;52:8-14.

[5] Jacobs MS, Windeler AS. An investigation of dental luting cement solubility as a function of the marginal gap. J Prosthet Dent 1991;65(3):436-42.

[6] Grasso JE, Nalbandian J, Sanford C, et al. Effect of restoration quality on periodontal health. J Prosthet Dent 1985;53(1):14-9.

[7] Janenko C, Smales RJ. Anterior crowns and gingival health. Aust Dent J 1979;24(4):225-30.

[8] Bona DA, Kelly JR. The clinical success of all-ceramic restorations. J Am Dent Assoc 2008;(Suppl 139):8S-13S.

[9] McLean JW, Von Fraunhofer JA. The estimation of cement film thickness by an in vivo technique. $\mathrm{Br}$ Dent J 1971;131(3):107-11.

[10] Samet N, Resheff B, Gelbard S, et al. A CAD/CAM system for the production of metal copings for porcelain-fusedto-metal restorations. J Prosthet Dent 1995;73(5):45763.

[11] Mou SH, Chai T, Wang JS, et al. Influence of different convergence angles and tooth preparation heights on the internal adaptation of Cerec crowns. J Prosthet Dent 2002;87(3):248-55.

[12] Bindl A, Mormann WH. Fit of all-ceramic posterior fixed partial denture frameworks in vitro. Int J Periodontics Restorative Dent 2007;27(6):567-75.

[13] Beuer F, Schweiger J, Edelhoff D. Digital dentistry: an overview of recent developments for CAD/CAM generated restorations. Br Dent J 2008;204(9):505-11.

[14] Ramirez-Sebastia A, Bortolotto $T$, Roig $M$, et al. Composite vs ceramic computer-aided design/computerassisted manufacturing crowns in endodontically treated teeth: analysis of marginal adaptation. Operative Dentistry 2013;38(6):663-73.
[15] Abo-Elmagd AA, Abdel-Aziz M. Influence of marginal preparation design on microleakage and marginal gap of endocrown cemented with adhesive resin cement. Egyptian Dental Journal 2015;61:5481-9.

[16] Rajan BN, Jayaraman S, Kandhasamy B, et al. Evaluation of marginal fit and internal adaptation of zirconia copings fabricated by two CAD - CAM systems: an in vitro study. J Indian Prosthodont Soc 2015;15(2):173-8.

[17] Gaintantzopoulou MD, El-Damanhoury HM. Effect of preparation depth on the marginal and internal adaptation of computer-aided design/computer-assisted manufacture endocrowns. Journal of Operative Dentistry 2016;41(6):607-16.

[18] El-Guindy J, El-Sheriff R, Aboul-Ezz AA. Evaluation of marginal discrepancy and microleakage of lava ultimate (resin nano ceramic) versus lithium disilicate (IPS E.Max CAD) endocrowns. In vitro study. Indian Journal of Scientific Research 2016;7(1):27-34.

[19] Dalloul R, Nassar JA, Al-Houri N. A comparative study of marginal fit between IPS E.MAX press crown and endocrown after cementation (In vitro). Clinical Medicine and Diagnostics 2016;6(5):122-5.

[20] Shin Y, Park S, Park JW, et al. Evaluation of the marginal and internal discrepancies of CAD-CAM endocrowns with different cavity depths: an in vitro study. J Prosthet Dent 2017;117(1):109-15.

[21] Darwish AH, Morsi TS, El Dimeery. Internal fit of lithium disilicate and resin nano-ceramic endocrowns with different preparation designs. Future Dental Journal 2017;3(2):67-72.

[22] Taha D, Spintzyk S, Sabet A, et al. Assessment of marginal adaptation and fracture resistance of endocrown restorations utilizing different machinable blocks subjected to thermomechanical aging. J Esthet Restor Dent 2018;30(4):319-28.

[23] Rocca GT, Daher R, Saratti CM, et al. Restoration of severely damaged endodontically treated premolars: the influence of the endo-core length on marginal integrity and fatigue resistance of lithium disilicate CAD-CAM ceramic endocrowns. Journal of Dentistry 2018;68:4150. 